\author{
Tatsiy Vasyl, \\ Doctor of Law, Professor, Rector of Yaroslav Mudryi \\ National Law University \\ ORCID: 0000-0001-6015-3058 \\ kancel@nulau.edu.ua \\ Danilyan Oleg, \\ Doctor of Philosophical Sciences, Professor, \\ Head of the Department of Phylosophy \\ of Yaroslav Mudryi National Law University \\ ORCID: 0000-0001-5308-4664 \\ odana@i.ua
}

\title{
LEGAL CULTURE AND STATE-BUILDING: CORRELATION SPECIFICS IN MODERN UKRAINE
}

The purpose of this work is to identify the main theoretical and methodological approaches to understanding the legal culture of the domestic society in modern conditions and to show its correlation with processes of building the democratic Ukrainian state. The methodology of research is a combination of general scientific and philosophical-legal methods, approaches and principles. Thus, the method of philosophical-legal reflection contributed to rethinking the latest experience of domestic nation-building and determining the role and place of legal culture in it. The structural-functional approach has become the basis for understanding the trends and problems in building a democratic state in Ukraine and the formation of an activist type of the legal culture in the national society. The scientific novelty of this work is the comprehensive disclosure of the interaction of nation-building processes and the establishment of the democratic legal culture in Ukraine. The study emphasizes that values of the legal culture of domestic society are actualized during nation-building and, vice versa, the democratic progress of our country contributes to the formation of legal knowledge, legal skills, positive legal stereotypes in public sense of justice. Conclusions. The development of the Ukrainian state is in dialectical unity with the development of the legal culture of the domestic society. A democratic state as an institution for the realization of democracy requires the existence of an activist legal culture of a democratic kind in the subjects of social relations. To date, Ukrainian citizens have gained a real opportunity to increase their influence on making decisions at the level of local self-government through the implementation of the reform of power decentralization. Such structural changes in the organization of power objectively contribute to the development of the legal culture of subsidiarity, which involves the rational distribution of powers and resources between central and local government, more active and responsible attitude of citizens towards socially significant issues. At the same time, the development of the legal culture and democratic progress of our state are hampered by the ineffectiveness of the judiciary and the law-enforcement system, confusion in legislative norms and regulations, corruption of state officials, the lack of legal education for young people, the influence of criminality on business and politics, the peculiarities of the mentality and the historical past of our people, etc.

Key words: legal culture; state-building; decentralization; democracy; activist legal culture.

Тацій Василь Якович, доктор юридичних наук, профессор, ректор Національного юридичного університету імені Ярослава Мудрого; Данильян Олег Геннадійович, доктор фрілософрських наук, професор, завідувач кафредри фрілософріі Національного юридичного університету імені Ярослава Мудрого

Правова культура та державотворення: особливості кореляції в сучасній Україні

Мета роботи - визначити основні теоретико-методологічні підходи до розуміння правової культури вітчизняного соціуму у сучасних умовах й показати ї̈ корелятивність з процесами розбудови демократичної Української держави. Методологія дослідження становить поєднання загальнонаукових та філософсько-правових методів, підходів й принципів. Так, метод філософсько-правової рефлексії сприяв переосмисленню новітнього досвіду вітчизняного державотворення та визначенню ролі й місця в ньому правової культури. Структурно-функціональний підхід став підґрунтям для розуміння тенденцій та проблем у розбудові демократичної держави в Україні й становлення у вітчизняному соціумі правової культури активістського типу. Наукова новизна роботи полягає у комплексному розкритті взаємодії державотворчих процесів та становленні демократичної правової культури в Україні. У дослідженні наголошується на тому, що цінності правової культури вітчизняного суспільства актуалізуються під час державотворення й навпаки демократичний поступ нашої країни сприяє формуванню правових знань, правових навичок, позитивних правових стереотипів у суспільній правосвідомості. Висновки. Розбудова Української держави знаходиться у діалектичній єдності з розвитком правової культури вітчизняного соціуму. Демократична держава як інститут втілення народовладдя передбачає наявність у суб' єктів суспільних відносин активістської правової культури демократичного ґатунку. На сьогоднішній день, українські громадяни отримали реальну можливість посилення впливу на прийняття рішень на рівні місцевого самоврядування завдяки здійсненню реформи децентралізації влади. Такі структурні зміни організації влади на місцях об' єктивно сприяють розвитку правової культури субсидіарності, яка передбачає раціональний розподіл повноважень та ресурсів між центральними й місцевими органами управління, більш активній та відповідальній позиції громадян щодо суспільноважливих проблем. Разом з тим, розвиток правової культури та демократичний поступ нашої держави гальмуються неефективністю судової влади та правоохоронної системи, плутаниною у законодавчих нормах й підзаконних актах, корумпованістю державних чиновників, відсутністю системи правового виховання молоді, впливом криміналітету на бізнес й політику, особливостями менталітету та історичного минулого нашого народу тощо.

Ключові слова: правова культура; державотворення; децентралізація; демократія; активістська правова культура.

Таций Василий Яковлевич, доктор юридических наук, профрессор, ректор Национального юридического университета имени Ярослава Мудрого; Данильян Олег Геннадьевич, доктор фрилософоских наук, профессор, заведующий кафредрой философии Национального юридического университета имени Ярослава Мудрого

Правовая культура и государственное строительство: особенности корреляции в современной Украине

Цель работы - определить основные теоретико-методологические подходы к пониманию правовой культуры отечественного социума в современных условиях и показать ее коррелятивность с процессами развития демократического Украинского государства. Методология исследования составляет сочетание общенаучных и философско-правовых методов, подходов и принципов. Так, метод философско-правовой рефлексии способствовал переосмыслению новейшего опыта отечественного государственного строительства и определению роли и места в нем правовой культуры. Структурнофункциональный подход стал основой для понимания тенденций и проблем в развитии демократического государства в Украине и становления в отечественном социуме правовой культуры активистского типа. Научная новизна работы

(C) Tatsiy V., 2019

(C) Danilyan O., 2019 
заключается в комплексном раскрытии взаимодействия процессов государственного строительства и становления демократической правовой культуры в Украине. В исследовании отмечается, что ценности правовой культуры отечественного общества актуализируются во время государственного строительства и наоборот демократический процесс в нашей стране способствует формированию правовых знаний, правовых навыков, позитивных правовых стереотипов в общественном правосознании. Выводы. Развитие Украинского государства находится в диалектическом единстве с развитием правовой культуры отечественного социума. Демократическое государство как институт воплощения народовластия предполагает наличие у субъектов общественных отношений активистской правовой культуры демократического толка. На сегодняшний день, украинские граждане получили реальную возможность усиления влияния на принятие решений на уровне местного самоуправления благодаря осуществлению реформы децентрализации власти. Такие структурные изменения организации власти на местах объективно способствуют развитию правовой культуры субсидиарности, которая предусматривает рациональное распределение полномочий и ресурсов между центральными и местными органами управления, более активной и ответственной позиции граждан по общественно-значимым проблемам. Вместе с тем, развитие правовой культуры и демократический процесс в нашем государстве тормозятся неэффективностью судебной власти и правоохранительной системы, путаницей в законодательных нормах и подзаконных актах, коррумпированностью государственных чиновников, отсутствием системы правового воспитания молодежи, влиянием криминалитета на бизнес и политику, особенностями менталитета и исторического прошлого нашего народа и т.д.

Ключевые слова: правовая культура; государственное строительство; децентрализация; демократия; активистская правовая культура.

Relevance of the topic. The pace and quality of the state-formation process in modern Ukraine are conditioned by purely legal and institutional factors, as well as by the level of spiritual progress of society. One of the manifestations of the spiritual maturity of the subjects of social relations is the degree of their legal culture development. The phenomenon of legal culture has a multifaceted manifestation, affecting various aspects of life of the modern democratic state: the nature of the state institutional and legal strategy; the quality of parliamentarism in general and law-making activity in particular; the degree to which the law is implemented in society; the level of violence and the nature of crime in the country, etc. Social significance of legal culture, its permanent influence on the course of state-formation processes in Ukraine has led to a multifaceted scientific reflection in this area.

Analysis of research and publications. In the modern scientific discourse, the theme of legal culture is quite popular, since a number of important processes for the state and society depends on its quality: the subject-object relations in the system of power, the efficiency of the activity of judicial and law-enforcement agencies, the level of crime in society, the success of implementation democratic reforms and so on. It is worth noting that a number of scientific works are devoted to understanding the value significance of legal culture as the basis of state formation, defining the determinant role of legal culture in the course of various social processes.

In particular, the researchers S. Tolmachova, S. Sitieva, A. Koltunova substantiate the idea that in the periods of socio-economic instability with the growth of protest mood, the activation of migration processes, the question of formation of legal culture of a person becomes of special relevancy. One of the main indicators of the formation of legal culture in society, along with the dynamics of the offenses commission is a tendency to deviant behavior [14, 1356]. Accordingly, the participation of citizens in protest actions, the presence in society of a certain percentage of subjects inclined to deviant behavior directly affect the stability of the state, the nature of the reforms.

In the scientific discussions of the present day, the problem of correlation of the concept "legal culture" with other concepts - "constitutional culture", "legislative culture", etc. - is actively negotiated. Thus, D. de Ruescher states that legal culture has an important institutional value and a powerful social effect. At the same time, the legal foundations of the state are closely connected to the legislative culture, which is based on principles, and not on empirical judgments [12]. Instead, researchers K. Kontiades and A. Fotiadu justify the expediency of using the notion of "constitutional culture", which is a kind (a subsystem) of legal culture [10].

In general, foreign experts note that legal culture remains fundamentally ambiguous concept. In their view, it is connected with the complexity of financing comprehensive studies, which compare legal cultures. As a rule, the study of legal cultures is rather one-dimensional or two-dimensional and focuses on the various formal features of the legal culture of a particular country, rather than on a transnational comparison [11].

Upon reviewing the existing reseach woks it can be stated that in domestic studies considerable attention is paid to the institutional and non-institutional dimensions of the existence of legal culture, in particular its dialectical interrelationship with the state formation. As $\mathrm{O}$. Makeyeva convincingly proves, legal culture is a powerful factor in the development of the legal system and plays one of the leading roles in the democratic transformations of modern Ukraine [3].

From the point of view of O. Makarova and Yu. Krylova, legal culture is the spiritually valuable core of nation building. It determines the formation of the legal system and civil society in the country, it forms the basis for the development of legal conscience of the population [2].

Thus, the analysis of scientific literature on this issue, marking out not yet sufficiently developed aspects of legal culture as a factor of democratic state formation, became the basis for the formulation of the purpose of the study. So, in our scientific research, we are planning to identify the main theoretical and methodological approaches to understanding the legal culture of domestic society in modern conditions and to show its correlation with the processes of building the democratic Ukrainian state.

Presentation of basic materials.

Deciding on the conceptual apparatus of our study, it is worth noting that the understanding of legal culture has various scientific interpretations and substantial shades.

According to domestic researchers, legal culture is a system of legal values that correspond to the level of legal progress achieved by society and reflect in a legal form the state of individual freedom, and other social values. It reflects the level of development of legal consciousness in society, the system of law and legislation, 
legal practice and legal science, covers the totality of all legal values created by people in the legal field. The high level of legal culture of society is one of the important features of civil society and the rule of law, which is based primarily on the principles of the rule of law and legal law, respect for the fundamental rights and freedoms of a man and a citizen. Therefore, legal culture and legal consciousness interact with the existence and functioning of each other [4, 425].

In turn, foreign scientists K. Kontiades and A. Fotiadu use the notion "constitutional culture", which is a kind (a subsystem) of legal culture. In particular, they state that "constitutional cultures reflect the general understanding and attitude to the constitution. The constitutions appear and are adopted within the framework of a certain legal culture, and also act, are applied, interpreted, and developed within the framework of this legal culture and with its help" [10, 207].

From the point of view of $D$. Nelken, in the present realities the concept of legal culture is often used to characterize the differences between legal systems (for example, presented in the tendencies of the existence of judicial and penitentiary institutions). According to the aforementioned expert, it is recommended to use it in the explaining the reasons that determine different attitudes of citizens and societies to the enforcement of the law. The concept of legal culture also finds its place in the assessment of pluralistic interactions between different types of law and in the attempts to understand how international or mixed courts overcome controversial cultural norms that are reflected in judicial practice of different jurisdictions [13, 46].

In the domestic philosophical and legal tradition, the tendency towards a combination of "institutional" and "non-institutional" understanding of the foundations of the legal culture existence is traced. Thus, according to I. Yakovyuk, legal culture is not an ordinary structural element of the legal system, as, being its qualitative characteristic, it is the characteristic of all spheres of legal life of society. That is, legal culture is a criterion on the basis of which one can assess the degree of development of the legal system and its structural elements according to their correspondence to that state that the implementation of the dominant model of statehood in a society requires. [9, 47].

One can agree with the statement of this scholar that the type, character, basic determinants of the legal culture of society as a whole reflect the peculiarities of the state-building progress of a certain people. At the same time, the deformed legal culture of individual citizens and segments of the population negatively affects the pace of democratic transformations in the state, in particular, in Ukraine.

Continuing the aforementioned logic, $\mathrm{O}$. Makeyeva points that it is precisely the legal culture as a factor in the development of the legal system must play a leading role in the democratic transformations in Ukraine; it is closely linked with all elements of the legal system, the formation of the citizens' legal consciousness, the new vision of the state as the democratic, sovereign and independent, the awareness of the relationship between law and laws, with the recognition of the priority role of a person and a citizen in legal relations. It is important to form legal values which, by their qualitative property, contribute to the legal development of an individual, the positive nature of his/her legal activity, the real provision of the highest value - the realization, protection of human rights [3, 51].

In our time, the course and results of structural reforms in Ukraine are also determined by the legal culture of the subjects of their implementation. The level of legal knowledge, legal skills, and the development of the legal consciousness of the participants in the nation building condition the success of the ultimate goal, which is the development of the democracy and the rule of law state in Ukraine.

The experts convincingly prove that without a high level of legal awareness and legal culture of each individual citizen of Ukraine, realization of the goals proclaimed by the Constitution is impossible. In particular, O. Makarova and Yu. Krylova point out that legal culture is a fundamental factor in the process of nation building, it contributes to the formation of the legal system and civil society in the state, since only on the basis of a highly developed civil society and the rule of law it is possible to build a true democratic state with a law-aware population. Building the rule of law state without raising the legal culture and the level of citizens' legal awareness is impossible. Increasing the level of legal culture of society, in turn, requires an increase in the level and quality of the organization of legal education, which is carried out through education, propaganda, agitation and selfeducation [2, 105].

Obviously, the legal culture determines in the final dimension the fate of political and legal reforms, the reform of the judicial system, of the legal acts and institutions. It depends on the level of legal culture whether they will act or not. The most important function of legal culture in modern society is the formation of legal conditions, in which the discussion is conducted, discussions of issues of common interest both for individual persons and the state, public opinion and expectations are formed [7, 291-292].

At the same time, there are a number of reasons in Ukrainian society that hinder the development of the democratic legal culture and reduce the quality of institutional transformations in the state. Among them one can distinguish the following: the absence of the theoretically grounded state conception of the formation of the legal culture of the population of Ukraine; the weakness and disorganization of the social institutions that should be involved in this process; the lack of the necessary number of trained legal experts for legal education of the citizens and the formation of their skills in legal behavior, etc. All this complicates already difficult situation connected with the formation of legal culture in the country and the implementation of legal reform in Ukraine [5, 212].

In our time, the considerable negative influence on the development of the legal culture of all subjects of nation formation is made by the ineffectiveness of the judicial and law-enforcement systems that are incapable of fully implementing the principle of "inevitability of punishment", and as a consequence, of the establishment of social justice.

According to O. Punko, the activity of the judiciary, the structure of which includes the Constitutional Court of Ukraine, the general courts headed by the Supreme Court of Ukraine and the system of arbitration courts, is of 
great importance for the legal education and citizens' culture. The judges and the judiciary organs facilitate the acquisition by citizens of complete, accurate and specific legal information, the formation of their law-abidingness, etc. Legal knowledge received by the citizens in courts has an important preventive value. It is necessary to increase the role of this function of the courts by translating the most important from the point of view of public opinion court processes, by improving the practice of participating of public prosecutors and public defenders in the trials, by increasing the time of admission of the citizens by judges, etc. [6, 45-46].

The arbitrariness of officials, corruption, non-compliance with legal norms by the representatives of power at different levels of the state administrative apparatus also do not contribute to the formation of the democratic legal culture. That is why Ukraine needs further development of democratic nation formation, an activist type of legal culture, qualitative reforms in the interaction of a person and state institutions.

In this sense, we emphasize that the logic of the development of the democratic state requires continuous improvement of the mechanisms and forms of people's representation in the government, creation of institutional and regulatory conditions for increasing the influence of citizens on the decision-making at the national and local levels. In our opinion, the fulfillment of these tasks requires qualitative changes in the legal culture of both society as a whole and individual citizen. Social activity and civic responsibility of a person and various segments of the population should become a pledge of continuous improvement of democratic procedures in our state and promote the accountability of the people in power to the society for their actions.

At the present stage of the national state-building, the above-mentioned imperatives of the democratization of the public life have been manifested in the implementation of the decentralization of power. In this context, the legal culture of subsidiarity, which provides for a rational distribution of functions, rights and responsibilities between all levels of government, becomes of a particular importance. In order to achieve this goal, the government system in the regions of Ukraine should provide real opportunity for a person to receive the maximum amount of services from the authorities. This task will be realized under many conditions, one of which is to increase the level of legal culture of subsidiary management personnel by overcoming existing deformations of the legal consciousness. Due to the active participation of local communities in public affairs, the quality of governance both of particular territories of Ukraine and the state as a whole can be improved. For Ukraine, the establishment of the local self-government institution as an integral attribute of civil society and an innovative entity of state-building is extremely important. At the same time, for the qualitative growth of level of the legal culture subsidiarity of the people in power, who head local communities, the positive changes in their legal consciousness are important, as well as raising the level of personal responsibility for making administrative decisions. The development of legal culture of subsidiarity at the local level will contribute to solving the following tasks:

- improvement of the protection of the rights and freedoms of citizens;

- increasing the strictness to the candidates for the local deputies and local self-government bodies in general;

- creating comfortable conditions for the development of citizens at the expense of equitable redistribution of local budgets and the adoption of balanced solutions taking into account the interests of the communities;

- implementation of the partnership philosophy in the triangle of central government - organs of the local self-government - citizen [1, 42-43].

In general, as the European experience of state-building shows, the legal culture of citizens evolves under the influence of the general democratization of public life, the real provision of opportunities for a legal way to defend their own interests in court, with the help of political parties and public organizations, lobby groups, etc.

Experts say that the ideological concepts that establish an opportunity to overcome modern problems of state-building are scientificly developed. Based on the mental achievements of the European civilization of our time, the relevant value orientations have been worked out and fixed, the central among which are the following:

- democracy which is genuine, representative, not decorative;

- the rule of law state based on well-known principles laid down primarily in the Declaration of Human Rights and in other international standards;

- implementation of the principle of responsibility of the state to the citizen in the state-building mechanism;

- embodiment of a fundamental European value - a developed civil society;

- pluralistic party structurization of society, which expresses the interests of all social groups of the population without exception, and is a fundumental precondition for the development and approval of the system of social discourse, that is, diverse and constant social dialogue;

- care for the middle class;

- care for the sphere of "subtle structures": literature, art, all possible civil unions, etc. - not only as crucial means of survival in the conditions of the information society, but as the deepest foundations of the existence of democracy and functioning of a full-valued civil society;

- recognition of law as the main resource of the modernization mechanism of state creation;

- formation of a national elite on the basis of the own national idea [8, 89-90].

The above-mentioned value orientations are the basis for the further development of the democratic legal culture of an activist type and the consistent implementation of systemic reforms in Ukraine. As it is known, the legal culture is formed under the influence of political, moral, socio-economic, spiritual and other factors and contains the so-called "institutional memory" about the experience of nation-building. Legal culture is the embodiment of customs, traditions, norms and ideas about the fair arrangement of the state, accumulated by a certain people (or society) during a long historical period.

Thus, the scientific novelty of the work is in the comprehensive disclosure of the interaction of state-building processes and the establishment of the democratic legal culture in Ukraine. The study emphasizes that the values 
of the legal culture of the domestic society are actualized during the nation-building and, vice versa, the democratic progress of our country contributes to the formation of legal knowledge, legal skills, positive legal stereotypes in social legal consciousness.

Conclusions. The development of the Ukrainian state is in dialectical unity with the development of the legal culture of the domestic society. A democratic state as an institution for the realization of democracy foresees the existence of an activist legal culture of a democratic kind in the subjects of social relations. To date, Ukrainian citizens have gained a real opportunity to increase their influence on the decision-making at the level of local selfgovernment through the implementation of decentralization of power reform. Such structural changes in the organization of power on the places objectively contribute to the development of the legal culture of subsidiarity, which involves the rational distribution of powers and resources between the central and local governments, a more active and responsible attitude of citizens towards socially significant issues. At the same time, the development of the legal culture and democratic progress of our state are hampered by the ineffectiveness of the judiciary and law-enforcement system, confusion in legislative norms and regulations, corruption of state officials, the lack of legal education for young people, the influence of criminality on business and politics, the peculiarities of the mentality and the historical past of our people, etc.

\section{תimepamypa}

1. Калиновський Ю. Ю., Жданенко С. Б. Роль правової культури субсидіарності у розвитку місцевого самоврядування в Україні. Сучасне суспільство: політичні науки, соціологічні науки, культурологічні науки : зб. наук. пр. 2012. Вип. 1. С. 33-41.

2. Макарова О. В., Крилова Ю. І. Проблеми формування правової культури в українському суспільстві. Науковий часопис НПУ імені М. П. Драгоманова. Серія 18: Економіка і право. 2015. Вип. 30. С. 104-108. 48-53.

3. Макеєва О. М. Правова культура як чинник розвитку правової системи. Юридичний вісник. Повітряне і космічне право. 2016. № 4. С.

4. Попадинець Г. О. Правосвідомість і правова культура як чинники становлення громадянського суспільства. Вісник Національного університету «Львівська політехніка». Серія: Юридичні науки : збірник наукових праць. 2016. № 850. С. $422-427$.

5.Правосвідомість і правова культура як базові чинники державотворчого процесу в Україні: монографія / Л. М. Герасіна, О. Г. Данильян, О. П. Дзьобань та ін. Харків : Право, 2009. 351 с.

6. Пунько О. В. Правове виховання як основний чинник формування правової культури особи в умовах розбудови правової держави України. Науковий вісник Ужгородського національного університету. Серія : Право. 2014. Вип. 27(1). С. 42-46.

7. Тацій В.Я. Вибрані статті, виступи, інтерв'ю (2009-2014) / упоряд.: О.В. Петришин, Ю.Г. Барабаш, В.І. Борисов; відп. за вип. О.В. Петришин. Харків: Право, 2015. $648 \mathrm{c.}$

8. Юськів Н. В. Правові проблеми державотворення у сучасних українських трансформаційних реаліях. Вісник Національного університету "Львівська політехніка". Юридичні науки. 2014. № 801. С. 86-91.

9. Яковюк І. Правова культура і її вплив на розвиток правової системи. Вісник Академії правових наук України. 2008. № 1 (52). С. $43-56$.

10. Contiades X., Fotiadou A. The Determinants of Constitutional Amendability: amendment models or amendment culture? European constitutional law review. 2016. Vol. 12. Issue 1. P. 192-211.

11. Damsa L. European Legal Cultures in Transition. Europe-Asia studies. 2017. Vol. 69. Issue 7. P. 1139-1140.

12. De Ruysscher D. Legal Culture, Path Dependence and Dysfunctional Layering in Belgian Corporate Insolvency Law. International insolvency review. 2018. Vol. 27. Issue 3. P. 374-397.

13. Nelken D. Comparative Legal Research and Legal Culture: Facts, Approaches, and Values. Annual review of law and social science. 2016. Vol. 12. P. 45-62.

14. Tolmacheva S., Siteva S., Koltunova A. Problem of studying social deviation and formation of legal culture of youth. International conference on research paradigms transformation in social sciences (rptss 2017). 2018. Vol. 35. P. 1356-1363.

\section{References}

1. Kaly`novs`ky`j, Yu. Yu., Zhdanenko, S. B. (2012). The role of the subsidiarity legal culture in the development of local government in Ukraine. Suchasne suspil'stvo: polity 'chni nauky”, sociologichni nauky', kul'turologichni nauky': zb. nauk. pr., issue 1, 33-41 [in Ukrainian].

2. Makarova, O. V., Kry lova, Yu. I. (2015). Formation problems of the legal culture in Ukrainian society. Naukovy`j chasopy`s NPU imeni M. P. Dragomanova. Seriya 18: Ekonomika i pravo, issue 30, 104-108 [in Ukrainian].

3. Makeyeva, O. M. (2016). Legal culture as a factor in the development of legal system. Yury 'dy 'chny`j visny`k. Povitryane i kosmichne pravo, 4, 48-53 [in Ukrainian].

4. Popady'necz', G. O. (2016). Legal awareness and legal culture as factors of the formation of a civil society. Visny'k Nacional'nogo universy'tetu «L'vivs'ka politexnika». Seriya: Yury'dy”chni nauky”: zbirny”k naukovy`x pracz', 850, $422-427$ [in Ukrainian].

5. Gerasina L.M., Danil'yan O.G., Dz'oban' O.P. et al. (2009). Pravosvidomist' i pravova kul'tura yak bazovi chynnyky derzhavotvorchoho protsesu v Ukrayini. Kharkiv : Pravo. [in Ukrainian].

6. Pun'ko, O. V. (2014). Legal education as the main factor in the formation of the legal culture of the individual in conditions of building the legal state of Ukraine. Naukovy`j visny`k Uzhgorods`kogo nacional'nogo universy`tetu. Seriya: Pravo, issue 27(1), 42-46 [in Ukrainian].

7. Tacij, V. Ya. (2015). Selected articles, speeches, interviews (2009-2014). Kharkiv: Pravo [in Ukrainian].

8. Yus'kiv, N. V. (2014). Legal problems of the state in the modern Ukrainian transformational realities. Visny'k Nacional'nogo universy' tetu "L`vivs 'ka politexnika". Yury dy'chni nauky', 801, 86-91 [in Ukrainian].

9. Yakovyuk, I. (2008). Legal culture and its influence on the development of the legal system. Visny'k Akademiyi pravovy'x nauk Ukrayiny', 1 (52), 43-56 [in Ukrainian].

10. Contiades, X., Fotiadou, A. (2016). The Determinants of Constitutional Amendability: amendment models or amendment culture? European constitutional law review, Vol. 12, issue 1, 192-211 [in English].

11. Damsa, L. (2017). European Legal Cultures in Transition. Europe-Asia studies, Vol. 69, issue 7, 1139-1140 [in English].

12. De Ruysscher, D. (2018). Legal Culture, Path Dependence and Dysfunctional Layering in Belgian Corporate Insolvency Law. International insolvency review, Vol. 27, issue 3, 374-397 [in English].

13. Nelken, D. (2016). Comparative Legal Research and Legal Culture: Facts, Approaches, and Values. Annual review of law and social science, Vol. 12, 45-62 [in English].

14. Tolmacheva, S., Siteva, S., Koltunova, A. (2018). Problem of studying social deviation and formation of legal culture of youth. International conference on research paradigms transformation in social sciences (rptss 2017), Vol. 35, 1356-1363 [in English]. 